\title{
Review
}

\section{Spasticity-assessment: a review}

\author{
F Biering-Sørensen ${ }^{*}, 1, \mathrm{JB}$ Nielsen ${ }^{2}$ and K Klinge ${ }^{1,2}$ \\ ${ }^{1}$ Clinic for Spinal Cord Injuries, the NeuroScience Centre, Rigshospitalet, Copenhagen University Hospital, Denmark; \\ ${ }^{2}$ Department of Medical Physiology, Panum Institute, University of Copenhagen, Copenhagen, Denmark
}

Study design: Review of the literature on the validity and reliability of assessment of spasticity and spasms.

Objectives: Evaluate the most frequently used methods for assessment of spasticity and spasms, with particular focus on individuals with spinal cord lesions.

Setting: Clinic for Spinal Cord Injuries, Rigshospitalet, University Hospital of Copenhagen, and Department of Medical Physiology, University of Copenhagen, Denmark.

Methods: The assessment methods are grouped into clinical, biomechanical and electrophysiological, and the correlation between these is evaluated.

Results: Clinical methods: For assessment of spasticity, the Ashworth and the modified Ashworth scales are commonly used. They provide a semiquantitative measure of the resistance to passive movement, but have limited interrater reliability. Guidelines for the testing procedures should be adhered to. Spasm frequency scales seem not to have been tested for reliability. Biomechanical methods such as isokinetic dynamometers are of value when an objective quantitative measure of the resistance to passive movement is necessary. They play a minor role in the daily clinical evaluation of spasticity. Electrophysiological methods: These techniques have provided valuable insight to the pathophysiological mechanisms involved in spasticity, but none of these techniques provide an easy and reliable assessment of spasticity for use in the daily clinic.

Conclusion: A combination of electrophysiological and biomechanical techniques shows some promise for a full characterization of the spastic syndrome. There is a need of simple instruments, which provide a reliable quantitative measure with a low interrater variability. Spinal Cord (2006) 44, 708-722. doi:10.1038/sj.sc.3101928; published online 25 April 2006

Keywords: spasticity; assessment; measurement; clinical methods; biomechanical methods; electrophysiological methods

\section{Introduction}

Spasticity is one of the most common and potentially disabling and bothersome complications affecting individuals with spinal cord lesion (SCL). Roughly, $70 \%$ of persons with SCL are spastic 1 year after injury, ${ }^{1}$ and around half of these receive antispastic medication. ${ }^{2}$

A quantitative assessment of spasticity and spasms is important for evaluation of potential effects of treatment interventions, but although spasticity is generally agreed to be easy to recognise, it is not easy to quantify. Therefore, the aim of the present review is to evaluate the reliability of the most frequently used methods for quantification of spasticity and to determine the correlation between the manual tests used in the clinic and the more objective and quantifiable biomechanical

*Correspondence: F Biering-Sørensen, Clinic for Spinal Cord Injuries, The Neuroscience Centre, Rigshospitalet, Copenhagen University Hospital, Havnevej 25, DK-3100 Hornbæk, Denmark and electrophysiological methods used for research purposes. Finally, based on our current knowledge, we will point to some future advances in the field.

\section{Definition and pathophysiology}

Spasticity may be defined as a motor disorder characterised by a velocity-dependent exaggeration of stretch reflexes (Figure 1), resulting from abnormal intraspinal processing of primary afferent input. ${ }^{3}$ Clinically this implies increased muscle tone, enhanced tendon reflexes, extended reflex zones and clonus. Spasms are sudden involuntary muscle contractions, which are characteristic for many individuals with SCL, in particular corresponding to knee-extension and hip-flexion.

The velocity dependency in the definition of spasticity distinguishes spasticity from other syndromes where changed resistance to passive movement of a joint may 

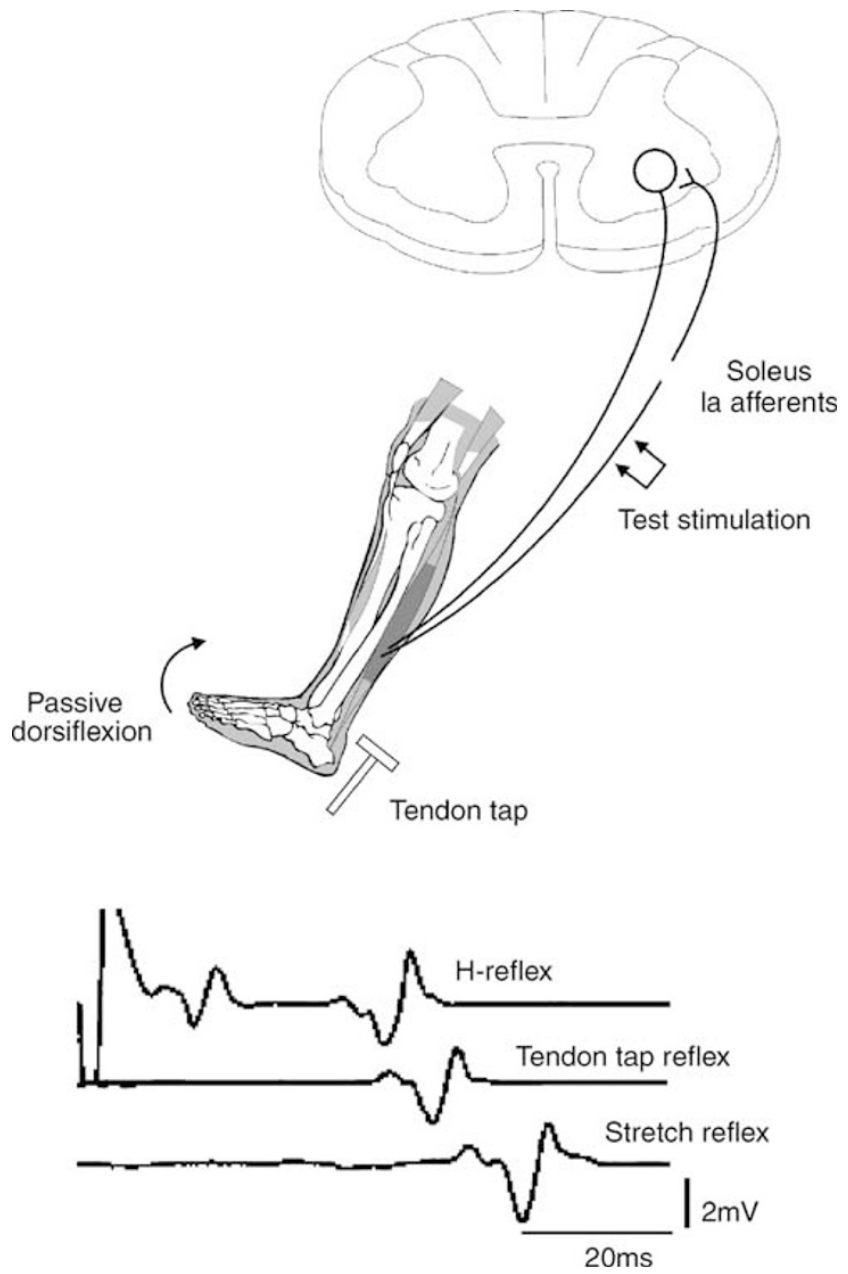

Figure 1 EMG used to measure the responses evoked by either stretching of the muscle (stretch reflex), tendon tap (T-reflex) or electrical stimulation of the peripheral nerve supplying the muscle (H-reflex) in order to evaluate whether these responses are exaggerated in spastic individuals and related to the degree of spasticity

be present, for example, the muscle rigidity in Parkinson patients and contractures. It is a particular problem of classification and definition that changes in the mechanical properties of muscles, such as stiffness, contractures, fibrosis and atrophy, are generally found in SCL patients ${ }^{4}$ and that a significant correlation between spasticity and contractures, reduced range of movement, is found. ${ }^{5}$ Such changes may be very difficult to distinguish from spasticity clinically. However, the distinction is of great importance both in relation to research, drug evaluation and choice of antispastic therapy.

The above definition of spasticity emphasises the exaggerated activity in the stretch reflex, which distinguishes spasticity from disorders such as dystonia. Muscle activity is thus not seen in spastic patients at rest, but only becomes manifest when the stretch reflex is activated voluntarily or involuntarily. Patients with spasticity may also have spasms. These patients will often be classified as spastic, although they may have perfectly normal stretch reflex activity and normal velocity-dependent muscle resistance. This likely reflects that affection of different central pathways is responsible for the development of exaggerated stretch reflexes (ie spasticity) and spasms. In patients with lesion of the lumbar spinal cord, stretch reflexes are often absent, although they may have abnormally high muscle resistance, which is more likely caused by contractures. Nevertheless, they often have severe spasms. Likewise, patients who have 'spastic gait' are usually classified as being spastic, although the relation between spastic gait and exaggeration of the stretch reflex is unclear.

Spasticity, spasms and spastic gait are all manifestations of a lesion of supraspinal motor pathways and it therefore makes good sense in the clinic not to dissociate them, but in research studies on the pathophysiology of spasticity or for development of new antispastic or rehabilitation therapy a distinction between these three manifestations of 'upper motor neuron lesion' may be of importance.

Spasticity defined as above is caused by adaptive changes in transmission in the spinal networks distal to a lesion of descending motor pathways. Selective lesion of the pyramidal tract does not lead to spasticity, whereas lesion of descending pathways from the brainstem as well as the cortical control of these pathways does. ${ }^{6,7}$ In individuals with SCL, impaired transmission in different spinal inhibitory pathways, such as reciprocal inhibition and presynaptic inhibition, has been found ${ }^{8-10}$ (Figure 2), which probably contributes to exaggeration of reflex activity and the increased muscle tone in the spastic patients. Evidence that changes in the properties of spinal motoneurones contribute to the development of spasticity in animals following spinal cord injury has also been obtained, ${ }^{11,12}$ but the significance of such changes for the pathophysiology of spasticity in human is unclear. ${ }^{13}$

Spasticity is less severe in individuals with complete SCL, and is more severe in those with minimal sparing of voluntary movement. ${ }^{1,2,5}$

The degree of spasticity varies from insignificant to very severe disability. There may also be a fluctuation in the spasticity during the day, and this seems more pronounced in persons with cervical SCL. ${ }^{14}$ In addition, spasticity may not be elicited by movement provocation on physical examination in $40 \%$ of the patients who report spasticity. ${ }^{5}$

\section{Assessment}

A variety of outcome measures in spasticity management exist. ${ }^{15}$ Recently detailed reviews of clinical, biomechanical and neurophysiological methods for spasticity evaluation have been published. ${ }^{16-18}$ In the present review, we evaluate some of the more common methods for assessment of spasticity, and our focus will be on individuals with SCL in particular. 


\section{Clinical methods}

The Ashworth and modified Ashworth scales

The most frequently used clinical methods for estimation of spasticity are the Ashworth Scale (AS) and the Modified Ashworth Scale (MAS) ${ }^{19,20}$ (Table 1).

The AS is simple, requires no instrumentation and is easy and quick to carry out, and has been used in a number of studies (see eg Tables 2, 5, and 6). Bohannon

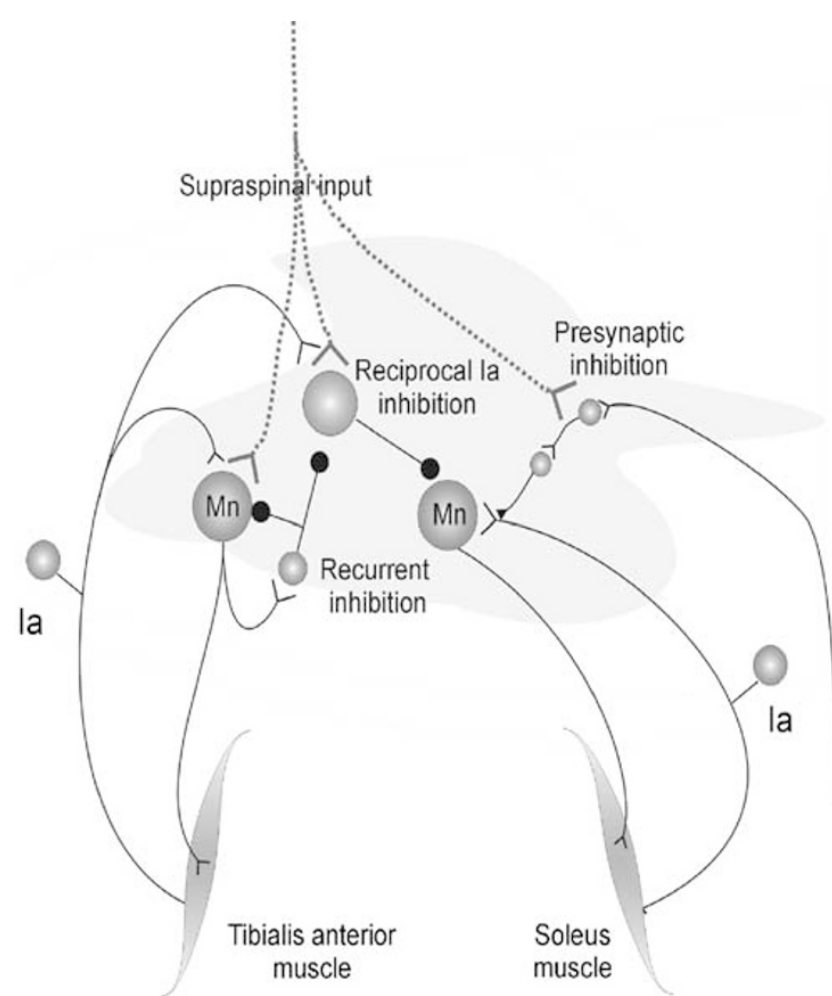

Figure 2 Illustration of pathways with documented impaired transmission in spasticity, that is, the presynaptic inhibition of the terminals of stretch reflex afferents and the postsynaptic reciprocal Ia inhibition between antagonistic muscles and Smith $^{20}$ found that many of their patients demonstrated levels of spasticity towards the lower end of the scale and included an extra category $(1+)$ to render the scale more discrete. At the same time, they modified the definitions slightly (Table 1).

The interrater reliability of the two tests has been tested in several studies. In addition, four studies have evaluated the intra-rater reliability of MAS (Table 2).

It was concluded by Sloan et $a l^{21}$ that MAS has an acceptable interrater reliability for testing of upper limb spasticity, but not so for testing of lower limb spasticity.

Nuyens et $a l^{22}$ found AS to be more reliable for muscles of the ankle than for muscles of the knee, and least reliable for muscles of the hip. There is a risk of using a summated AS score as in this study, because this may mask unreliability arising from the use of individual muscle scores. ${ }^{26,28}$

Haas $e t a l^{23}$ investigated the interrater reliability for both AS and MAS in 30 SCL patients. As in the study by Bohannon and Smith, ${ }^{20}$ the lower end scores were used more frequently; score 4 was used in only eight instances. They also found that score 0 was easier to rate than the other scores. The interrater reliability varied between AS and MAS, between muscle groups (ie worst for plantar flexors, followed by hip extensors and flexors and best for hip adductors) and different limbs. It was recommended that the scales should be used with caution when measuring spasticity in the lower limbs in individuals with SCL. The use of inexperienced assessors has been questioned, ${ }^{29}$ but future studies are needed to evaluate the effect of training on the reliability of the scales. ${ }^{23,27}$

Allison et $a l^{24}$ found for plantar flexor muscles that the interrater reliability was significantly lower than reported for elbow flexor spasticity by Bohannon and Smith. ${ }^{20}$ They argued that there was no support for a continued use of the MAS scale to evaluate plantar flexor spasticity in persons with traumatic brain injury. The limited reliability of the MAS scale for testing of plantar flexor spasticity may be speculated to be due to a shorter lever arm at the ankle, which makes it difficult

Table 1 The Ashworth and Modified Ashworth scales ${ }^{19,20}$

\begin{tabular}{lcl}
\hline Ashworth scale & Score & Modified Ashworth scale \\
\hline $\begin{array}{l}\text { No increase in tone } \\
\begin{array}{l}\text { Slight increase in tone giving a 'catch' when the limb was } \\
\text { moved in flexion or extension }\end{array}\end{array}$ & $\begin{array}{l}\text { No increase in muscle tone } \\
\text { Slight increase in muscle tone, manifested by a catch and } \\
\text { release or by minimal resistance at the end range of motion } \\
\text { when the affected part(s) is moved in flexion or extension }\end{array}$ \\
More marked increase in tone but limb easily flexed & $1+(2)$ & $\begin{array}{l}\text { Slight increase in muscle tone, manifested by a catch, } \\
\text { followed by minimal resistance throughout the remainder } \\
\text { (less than half) of the ROM }\end{array}$ \\
Considerable increase in tone - passive movement difficult & 3 (4) $\begin{array}{l}\text { More marked increase in muscle tone through most of the } \\
\text { ROM, but the affected part(s) is easily moved } \\
\text { Considerable increase in muscle tone, passive movement is } \\
\text { difficult }\end{array}$ \\
Limb rigid in flexion or extension & 4 (5) Affected part(s) rigid in flexion or extension
\end{tabular}

ROM, range of movement

In bracket, transcription sometimes used for the Modified Ashworth Scale 
Table 2 Publications with intra- and inter-rater reliability for Ashworth and Modified Ashworth scale

\begin{tabular}{|c|c|c|c|c|c|c|c|c|c|}
\hline Authors & Participants & $\begin{array}{l}\text { Tester }(s) \text { test } \\
\text { used }(A S / M A S)\end{array}$ & $\begin{array}{l}\text { Joint }(s) \text { and } \\
\text { movement - } \\
\text { muscles }\end{array}$ & $\begin{array}{l}\text { Training or } \\
\text { standardisation }\end{array}$ & $\begin{array}{l}\text { Repetitions for } \\
\text { each rating }\end{array}$ & $\begin{array}{l}\text { Time for each } \\
\text { movement }(s)\end{array}$ & $\begin{array}{l}\text { Distribution of } \\
\text { ratings }\end{array}$ & $\begin{array}{l}\text { Intra-rater } \\
\text { reliability } \\
\text { comments }\end{array}$ & $\begin{array}{l}\text { Inter-rater } \\
\text { reliability } \\
\text { comments }\end{array}$ \\
\hline $\begin{array}{l}\text { Bohannon and } \\
\text { Smith }^{20}\end{array}$ & $\begin{array}{l}\text { Twenty-four } \\
\text { cerebrovascular } \\
\text { Five closed head } \\
\text { injury } \\
\text { One multiple } \\
\text { sclerosis }\end{array}$ & $\begin{array}{l}\text { Two experienced } \\
\text { therapists (MAS) }\end{array}$ & $\begin{array}{l}\text { Elbow flexors } \\
\text { Weaker side } \\
\text { tested }\end{array}$ & $\begin{array}{l}\text { Procedure } \\
\text { described }\end{array}$ & $5-8$ & 1 & $\begin{array}{l}\text { Mainly } 0-1 \text { score. } \\
\text { Less } 1+\text { to } 2 \\
\text { Two times } 3 \text {, and } \\
\text { no score } 4 \text {. }\end{array}$ & - & $\begin{array}{l}\text { Agree } 86.7 \%, \\
\text { never disagreed } \\
\text { more than one } \\
\text { grade } \\
\tau 0.85(P<0.001)\end{array}$ \\
\hline Sloan $e t a l^{21}$ & $\begin{array}{l}\text { Hemiplegia } \\
31 \text { stoke } \\
\text { Three head injury }\end{array}$ & $\begin{array}{l}\text { Two } \\
\text { physiotherapists } \\
\text { Two doctors } \\
\text { (MAS) }\end{array}$ & $\begin{array}{l}\text { Elbow flexors } \\
\text { and extensors } \\
\text { Knee extensors }\end{array}$ & $\begin{array}{l}\text { Period of } \\
\text { training. } \\
\text { Procedure } \\
\text { described }\end{array}$ & 4 & 1 & $?$ & - & $\begin{array}{l}\text { Mean } \rho 0.45- \\
0.74 \text {, lowest for } \\
\text { knee flexion. } \\
\text { Mostly } P<0.01 \text {, } \\
\text { but not for the } \\
\text { knee }\end{array}$ \\
\hline Nuyens et $a l^{22}$ & $\begin{array}{l}\text { Thirty multiple } \\
\text { sclerosis }\end{array}$ & $\begin{array}{l}\text { Two } \\
\text { physiotherapists } \\
\text { one with much } \\
\text { larger experience } \\
\text { in neurological } \\
\text { assessment (AS) }\end{array}$ & 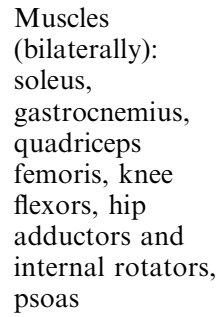 & $\begin{array}{l}\text { Preliminary trial. } \\
\text { Procedure } \\
\text { described }\end{array}$ & $1-2$ (mostly) & Quickly & $\begin{array}{l}\text { Highest } \\
\text { frequency for } 0 \text {, } \\
\text { but } 1-4 \text { well } \\
\text { represented }\end{array}$ & - & $\begin{array}{l}\tau 0.24-0.86 \\
(P=0.143- \\
0.0001), \text { more } \\
\text { reliable for } \\
\text { muscles of the } \\
\text { ankle than knee } \\
\text { and hip, lowest } \\
\text { for hip adductors } \\
\text { and internal } \\
\text { rotators }\end{array}$ \\
\hline Haas et $a l^{23}$ & $\begin{array}{l}\text { Thirty spinal } \\
\text { cord injury }\end{array}$ & $\begin{array}{l}\text { Phsysiotherapist } \\
\text { and doctor } \\
\text { experienced in } \\
\text { spinal cord injury } \\
\text { rehabilitation } \\
\text { (AS and MAS) }\end{array}$ & $\begin{array}{l}\text { Hip adductors, } \\
\text { extensors and } \\
\text { flexors } \\
\text { Ankle plantar } \\
\text { flexors }\end{array}$ & $\begin{array}{l}\text { No formal } \\
\text { training in the } \\
\text { spasticity scales } \\
\text { Procedure } \\
\text { described }\end{array}$ & 3 & 1 & $\begin{array}{l}\text { Lower scores } \\
\text { used more } \\
\text { frequently } \\
\text { Eight scored } 4\end{array}$ & - & $\begin{array}{l}\text { Agree } 40.0 \%- \\
72.4 \%, \kappa 0.20- \\
0.62 \text {. Poorest for } \\
\text { plantar flexors. } \\
\text { Highest } \\
\text { agreement for } \\
\text { score } 0 . \text { Overall } \\
\text { reliability only } \\
\text { fair }\end{array}$ \\
\hline Allison et $a l^{24}$ & $\begin{array}{l}\text { Thirty traumatic } \\
\text { brain injury }\end{array}$ & $\begin{array}{l}\text { Two experienced } \\
\text { physiotherapists } \\
\text { (MAS) }\end{array}$ & $\begin{array}{l}\text { Ankle plantar } \\
\text { flexors }\end{array}$ & $\begin{array}{l}2 \text { months } \\
\text { training. } \\
\text { Procedure } \\
\text { described }\end{array}$ & $5-8$ & $1 / 2$ & $\begin{array}{l}\text { Score } 0 \text { most } \\
\text { frequent to very } \\
\text { few } 4\end{array}$ & $\begin{array}{l}\text { Agree } 48-53 \% \\
\rho 0.55 \text { and } 0.74, \\
\kappa 0.29 \text { and } 0.69 \\
\tau \text {-b } 0.48 \text { and } 0.67\end{array}$ & $\begin{array}{l}\text { Agree } 55 \% . \rho \\
0.73, \kappa 0.40, \tau \text {-b } \\
0.65 . \text { Reliability } \\
\text { for plantar } \\
\text { flexors less } \\
\text { optimal }\end{array}$ \\
\hline Gregson et $a l^{25}$ & $\begin{array}{l}\text { Thirty-two acute } \\
\text { stroke }\end{array}$ & $\begin{array}{l}\text { Two senior } \\
\text { physiotherapists } \\
\text { (MAS) }\end{array}$ & Elbow flexors & $\begin{array}{l}\text { Training before. } \\
\text { Procedure } \\
\text { described }\end{array}$ & $\begin{array}{c}4 \text { (average score } \\
\text { used) }\end{array}$ & 1 & $?$ & $\begin{array}{l}\text { Agree } 32 \% . \\
K_{\mathrm{w}} 0.83\end{array}$ & $\begin{array}{l}\text { Agree } 66 \%, \\
K_{\mathrm{w}} 0.84\end{array}$ \\
\hline Gregson et $a l^{26}$ & $\begin{array}{l}\text { Thirty-five acute } \\
\text { stroke }\end{array}$ & $\begin{array}{l}\text { Research medical } \\
\text { registrar and } \\
\text { research } \\
\text { physiotherapist } \\
\text { (MAS) }\end{array}$ & $\begin{array}{l}\text { Elbow flexors } \\
\text { Wrist flexors } \\
\text { Knee flexors/hip } \\
\text { extensors } \\
\text { Ankle } \\
\text { dorsiflexors }\end{array}$ & $\begin{array}{l}\text { Written } \\
\text { guidelines }\end{array}$ & $\begin{array}{c}3 \text { (lowest score } \\
\text { used) }\end{array}$ & 1 & $?$ & $\begin{array}{l}\text { Elbow: Agree } \\
62-72 \%, \\
\kappa 0.39-0.53, \\
K_{\mathrm{W}} 0.77-0.83 . \\
\text { Wrist: Agree } \\
59-71 \% \\
\kappa 0.35-0.48, \\
K_{\mathrm{W}} 0.80-0.88 .\end{array}$ & $\begin{array}{l}\text { Elbow: Agree } \\
59-78 \%, \\
\kappa 0.34-0.67, \\
K_{\mathrm{W}} 0.77-0.96 . \\
\text { Wrist: Agree } \\
66-71 \%, \kappa \\
0.43-0.51, \\
K_{\mathrm{W}} 0.84-0.89 .\end{array}$ \\
\hline
\end{tabular}




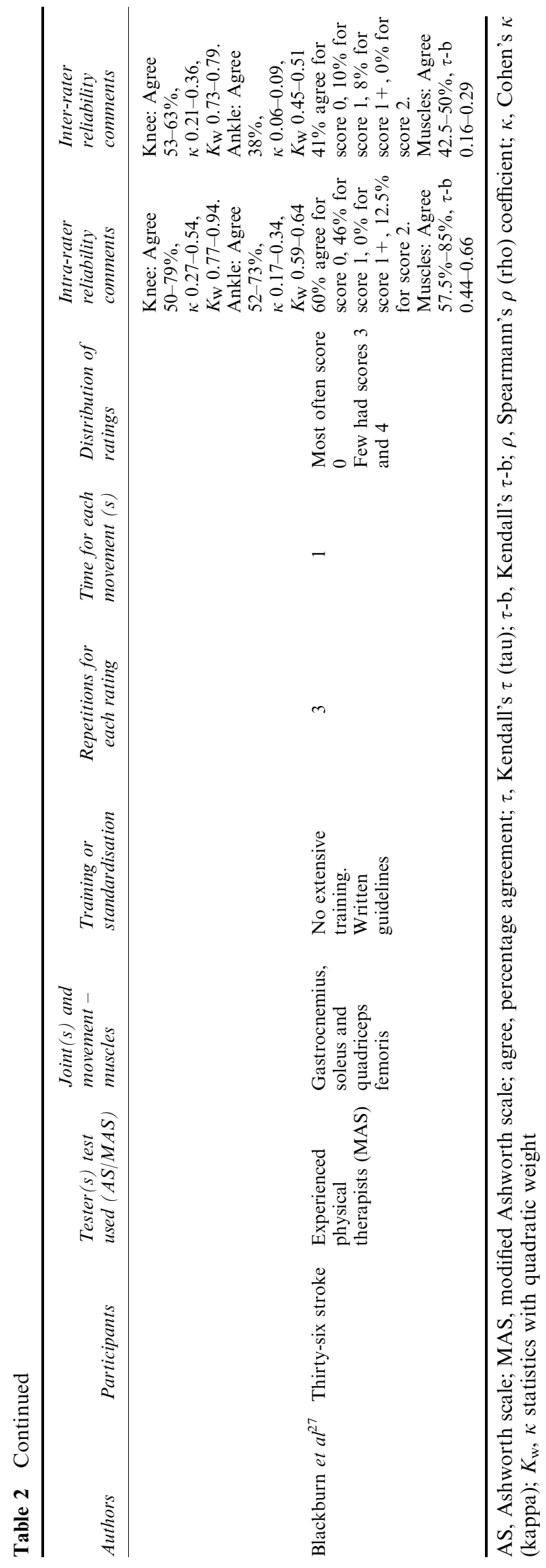

to determine the resistance during the movement. In addition, it was pointed out that the terminology used in the description of the grades in MAS (Table 1) may contribute to the interrater disagreement due to varied interpretation, that is, terms like 'slight increase', 'minimal resistance', 'more marked increase', 'part easily moved', 'considerable increase' and 'passive movement difficulty'.

Gregson $e a l^{25,26}$ found the intra- as well as the interrater reliability for the MAS is good to very good for elbow, wrist and knee, but less satisfactory over the ankle, which is in disagreement with the reported findings by Nuyens et al. ${ }^{22}$ The importance of standardised, written guidelines for the measurement to improve the intra- and inter-rater agreement is stressed. ${ }^{25,26}$

Blackburn et $a l^{27}$ assessed the inter- and intra-rater reliability of MAS, and found an acceptable intra-rater, but a poor inter-rater reliability. Because most agreement was obtained for score 0 , they concluded that reliable measurements to establish whether normal or low muscle tone is present may be obtained by MAS.

\section{Overall evaluation of the $A S$ and $M A S$}

Based on the above and the results in Table 2, several issues seem of importance. The characteristics of spasticity likely depend to some extent on the aetiology, which may impose certain variability in the reported evaluation and explain some of the differences in the studies. The circumstances under which the individuals have been tested, such as the time of the day, hours and type of activity before the test, ambient temperature, emotional status, general health (such as urinary tract infection, constipation, pain, fatigue), use of drugs, clothing and especially the testing position, that is, all not controlled factors may contribute to variability in the scores. In addition, the possibility that the degree of spasticity may change for a given test person between tests should be considered. ${ }^{24}$

For research purposes, it is essential that the rater has received adequate training before commencing the testing procedure, and that well-described standardized procedures are available and adhered to. Because of the high inter-rater variability, it is recommended that only one rater performs all the tests in an investigation.

In relation to the test procedure, Pandyan et $a l^{28}$ stress that the resistance in the viscoelastic elements of the muscle will decrease with repeated stretching, and that the number of repetitions during the testing of the particular muscle therefore should be kept to a minimum. Since spasticity is velocity dependent by definition, the speed of movement of the specific joint is of importance. Most studies report that $1 \mathrm{~s}$ was used for the movement, but precise measurements have not been performed and the range of movement and thus also the speed of movement used in the studies is unclear. Because a certain speed in the movement seems necessary to elicit the stretch reflex, ${ }^{30,31}$ it may be feared that too slow movements may have been used in several 
studies for proper evaluation of the spasticity. In order to determine a possible influence from passive muscle structures, it is also necessary to manipulate the limb at a speed below the threshold of stretch reflex activity and to compare the resistance at this speed to the resistance generated at higher speeds of movement. It has been recommended to include information of passive range of movement, the resting limb posture before stretch and possible pain elicited during the stretch. ${ }^{28}$ If the range of movement is decreased, for example, due to contracture, one has to be aware that the results obtained from clinical spasticity assessment may as well be limited. Likewise, if pain is present during the procedure, the value of the measurements may be questionable. However, for both of these issues, we have not found any studies, which have evaluated this specifically.

For the movements/muscle groups tested, it looks as if the reliability is generally better in the upper than in the lower limb. However, determining whether reliability for AS/MAS is 'acceptable' remains problematic. Although some reliability has been reported in several of the studies, the statistics used may be questioned. The percentage agreement indicates how often the raters agreed in their scoring on the AS/MAS. The Cohen's Kappa $(\kappa)$ statistic gives a value of agreement corrected for chance. A significant $\kappa$ value shows that the agreements between the raters did not occur by chance. However, because the prevalence within each of the categories differed greatly due to the high frequency of scores of 0 , the data are skewed, and $\kappa$ may be an inappropriate statistic to use. ${ }^{27}$ On the other hand, Kendall's tau $(\tau)$ and Spearmann's rank correlation coefficient $(\rho)$ both assume a rank order between subjects. Further correlation coefficient is a measure of the strength of linear association between two variables, which is not the same as a measure of agreement. The choice of statistic may also depend on the number of raters included.

In the review by Pandyan et $a l^{28}$ it is concluded that 'AS can be used as an ordinal level measure of resistance to passive movement, but not spasticity. The MAS will need to be treated as a nominal level measure of resistance to passive movement until the ambiguity between the ' 1 ' and ' +1 ' grades is resolved.'

In a later editorial, Ward ${ }^{32}$ state that AS and MAS are in general use, and their reliability is good in some areas, but their validity in their general application to spasticity assessment is not, and its limitations should be realised.
These statements seem still valid, but in the only reliability study in individuals with SCL it is concluded that the AS/MAS seem not ideally suited for persons with SCL. ${ }^{23}$ On the other hand, Sköld ${ }^{14}$ found in a study of 45 individuals with SCL that there was a significant correlation between self-ratings of spasticity using a visual analogue scale (VAS) and the clinical rating with MAS.

From the pragmatic standpoint it can be concluded that AS/MAS may be used in the clinical setting as well in research. However, then it should be performed after appropriate training according to standardised procedures, which take into account the many possible, confounding factors mentioned above, and when used in research one rater only should be applied.

\section{Spasm frequency scales}

The original Penn spasm frequency scale ${ }^{33}$ was created to follow the effect of intrathecal baclofen in 20 patients with spasticity caused by multiple sclerosis and SCL (Table 3). For this purpose, the scale was sufficiently sensitive, whereas it may be less optimal for other purposes; in particular, when the treatment effect influences score 3 and $4 .^{35}$

An alternative spasm frequency score (Table 3) ranking spasm frequency per day has been suggested. ${ }^{34}$ In the article, a spasticity score is created from the product of the scores for the degree of muscle tone according to AS and the spasm frequency. Two physicians scored 10 patients and found close agreement for the composite spasticity score.

Priebe $e t a l^{36}$ found in a study of 85 individuals with SCL with varying degrees of spasticity weak relationships between the Penn spasm frequency scale and selfreport scales of interference with function and painful spasms. Various clinical examination scores, including the Penn spasm frequency scale, AS, standard scales of tendon taps, clonus, and plantar stimulation correlated poorly with each other, suggesting that they each assess different aspects of the spastic syndrome.

The spasm frequency may be counted as suggested, but one should be aware that the sensitivity may well depend upon the particular patient group tested. In addition, until now we do not have any reliability studies available.

\section{Biomechanical methods}

Isokinetic dynamometers have frequently been used for assessment and evaluation of spasticity. The great

Table 3 Penn spasm frequency scale ${ }^{33}$ and the Spasm frequency score ${ }^{34}$

\begin{tabular}{lcl}
\hline Penn spasm frequency scale & Score & Spasm frequency score \\
\hline No spasms & 0 & No spasms \\
Mild spasms at stimulation & 1 & One or fewer spasms per day \\
Irregular strong spasms less than 1 time $/ \mathrm{h}$ & 2 & Between 1 and 5 spasms per day \\
Spasms more often than 1 time $/ \mathrm{h}$ & 3 & Five to less than 10 spasms per day \\
Spasms more than 10 times $/ \mathrm{h}$ & 4 & Ten or more spasms per day, or continuous contraction \\
\hline
\end{tabular}


advantage is that they make a standardization of the applied stretch velocity and amplitude possible, and thereby are able to quantify the velocity-dependent resistance in the muscle to passive movement.

\section{Reliability of isokinetic dynamometer measurements}

The reliability and validity of isokinetic dynamometers (Kin-Com ${ }^{\circledR}$, Cybex) has been examined in several studies, ${ }^{37-42}$ from which it can be concluded that the resistive force values are highly reproducible for lowas well as high-angle velocities, and in able bodied as well as in individuals with cerebral palsy and SCL (Table 4).

\section{Muscle resistance to passive mechanical stretch and spasticity graded by AS or MAS}

In all the studies listed below it was attempted to quantify the resistance to passive flexion and/or extension of a joint at different stretch velocities, that is, quantifying the torque and its sensitivity to stretch velocity. Some have evaluated the total resistance in the muscle at different stretch velocities while others have tried to differentiate the intrinsic and the velocitydependent torque components. The latter studies, for example, Pisano et $a l^{43}$ have the advantage that they ignore morphological changes in the muscle due to inactivity or changes in neural control and thereby emphasize the hyper excitability and velocity-dependent increase in resistance/torque defined as spasticity. To evaluate spasticity, Firoozbakhsh et $a l^{44}$ measured the total resistance to passive extension and flexion of the knee joint at $30^{\circ}, 60^{\circ}$ and $120^{\circ} / \mathrm{s}$ (Table 5). They found significantly greater sum torque in individuals with SCL compared to the able-bodied group, and greater slope of the torque-velocity regression lines, showing a greater sensitivity to stretch velocity in the group with SCL.

Perell et $a l^{45}$ used the same experimental setting, and found in contrast to Firoozbakhsh et a ${ }^{44}$ significantly less peak resistance in spastic (AS score 2-4) compared to normal individuals. They also found lower resistance in the spastic compared to flaccid (AS score 0) individuals during passive flexion of the knee at $60^{\circ}$ and $120^{\circ} \mathrm{s}$. There was no significant difference in resistance between flaccid and normal individuals (Table 5). In addition, they found a significantly lower slope of the linear regression curve of the torque-velocity data in both directions in the spastic compared to the normal group and for spastic compared to flaccid group. This means that the group with SCL quite surprisingly showed a lower sensitivity to stretch velocity than the two other groups. However, one should be cautious with the interpretation of these results and results from other studies where torque measurements are taken at few velocities only. Since we do not know the threshold velocity for eliciting the stretch reflex in the different populations, we do not know if we compare torque measurements under different conditions. The spastic group might have a stretch reflex threshold below $30^{\circ} / \mathrm{s}$ and therefore have reached higher levels at this velocity, giving a lesser slope in the regression line within the measured velocities.

Perell et $a l^{45}$ demonstrated for all groups that peak torque in both directions increased linearly with the velocity of the knee motion. Further, it is interesting that they were able to classify $100 \%$ of the spastic, $90 \%$ of the normal and $67 \%$ of the flaccid individuals using discriminant analysis.

Franzoi et $a l^{46}$ got slightly different results, with the SCL group showing a significantly higher average peak torque in passive isokinetic flexion of the knee at $120^{\circ} / \mathrm{s}$ compared to the normal group. There was a significantly lower average torque in the SCL group with AS scores 1-2 compared to the normal group for extension of the knee at $60^{\circ}$ and $120^{\circ} / \mathrm{s}$, and correspondingly a higher average peak torque in the SCL group with the AS score 3 compared to the normal group at extension and flexion at $60^{\circ}$ and at $120^{\circ} / \mathrm{s}$ (Table 5). They state that the lower or equal peak torque in the SCL group with AS score 1-2 were comparable to data from a normal group reported by Perell et al. ${ }^{45}$ This comparison seems a bit dared, since the two studies used different AS scores for subdivision of SCL individuals (Table 5). Consequently, it is difficult to draw conclusions in this respect from the two studies.

Akman $e t a l^{47}$ found for the SCL group that resistive torque from hip abduction was significantly different from hip adduction, and ankle dorsal flexion was significantly different from ankle plantar flexion. Peak torque values were significantly higher in individuals with SCL compared to normal for each joint motion at all velocities. When differentiating between various grades of spasticity, individuals with AS score 1 showed no difference compared to normal in knee flexionextension and ankle dorsal flexion, while there was a significant difference in hip abduction. Further, AS score 2 was insignificantly different in knee flexionextension compared to normal (Table 5).

For the SCL group, the average peak torque values were positively correlated with the AS scores.

Pisano et $a l^{43}$ found stretch reflex threshold speed (determined from simultaneous electromyography (EMG) measurement) significantly lower in post-stroke individuals compared to controls. The stiffness indices were significantly higher in post-stroke individuals compared to controls (Table 5). These results indicate greater passive and reflex-mediated wrist stiffness in post-stroke individuals compared to controls. Finally they found high correlation between MAS and total stiffness index, MAS and stretch reflex threshold speed as well as between MAS and stretch reflex. It is interesting that MAS correlated so well with these measures.

Pandyan et $a l^{48}$ developed a portable custom build measurement device for evaluation of spasticity. With this device, the resistance to passive movement (RTPM) during extension of the forearm was measured. The assessor is moving the forearm during pain-free range of movement measuring MAS, while the device simultaneously measures RTPM, passive range of movement (PROM) and speed. At 1 week after stroke, RTPM in 
Table 4 Publications on test-retest reliability of isokinetic measurement device in spastic patients

\begin{tabular}{|c|c|c|c|c|c|c|}
\hline Author(s) & Participants & Joint movement & $\begin{array}{l}\text { Measurement device and } \\
\text { stretching velocity }\end{array}$ & Determination of resistance & $\begin{array}{l}\text { Intertrial reliability } \\
\text { (resistive torque) }\end{array}$ & $\begin{array}{l}\text { Coefficients of } \\
\text { variation }(C V)\end{array}$ \\
\hline $\begin{array}{l}\text { Boiteau } \\
\text { et } a l^{40}\end{array}$ & $\begin{array}{l}\text { Ten CP } \\
\text { (age } 2-7 \text { years) } \\
\text { Seven diplegia } \\
\text { Three hemiplegia }\end{array}$ & Ankle dorsal flexion & $\begin{array}{l}\text { Kin-Com }^{\circledR} \text { : } \\
10^{\circ} / \mathrm{s}(\mathrm{LV}) \\
190^{\circ} / \mathrm{s}(\mathrm{HV}) \\
\text { Hand-held dynamometer } \\
\text { (Penny and Giles): } \\
10-12^{\circ} / \mathrm{s} \text { (LV) } \\
70-100^{\circ} / \mathrm{s}(\mathrm{HV}) \\
\text { (velocities approximated) }\end{array}$ & $\begin{array}{l}\text { Kin-Com }{ }^{\circledR} \text { : } \\
\text { Mean resistive force from } \\
\text { three series of } 10 \text { passive } \\
\text { movements at LV and HV } \\
\text { Hand-held: } \\
\text { Mean resistive force from } \\
\text { three consecutive passive } \\
\text { movements at LV and HV }\end{array}$ & $\begin{array}{l}\text { Kin-Com }{ }^{\circledR} \text { : } \\
\text { ICC } 0.84 \text { at } \mathrm{LV} \\
\text { ICC } 0.84 \text { at } \mathrm{HV} \\
\text { Hand-held: } \\
\text { ICC } 0.79 \text { at } \mathrm{LV} \\
\text { ICC } 0.90 \text { at } \mathrm{HV}\end{array}$ & $\begin{array}{l}\text { Kin-Com }{ }^{\circledR} \text { : } \\
\text { Resistance } \\
11.8-12.8 \% \\
\text { Hand-held: } \\
\text { Resistance } \\
13.2-13.9 \%\end{array}$ \\
\hline $\begin{array}{l}\text { Lamontagne } \\
\text { et } a l^{41}\end{array}$ & $\begin{array}{l}\text { Nine SCL } \\
\text { Seven complete } \\
\text { Two incomplete } \\
1-5 \text { years post injury }\end{array}$ & Ankle dorsal flexion & $\begin{array}{l}\text { Kin-Com }{ }^{\circledR} \text { : } \\
\text { Hand-held dynamometer } \\
\text { Penny and Giles: } \\
5^{\circ} / \mathrm{s}(\mathrm{LV}) \\
180^{\circ} / \mathrm{s}(\mathrm{HV}) \\
\text { Maximal velocity was used } \\
\text { for the hand-held } \\
\text { dynamometer from } \\
\text { respective trials eliciting } \\
\text { stretch-reflex }\end{array}$ & $\begin{array}{l}\text { Resistive force from each of } \\
\text { five consecutive trials for } \\
\text { both velocities at }-5^{\circ} \text { of } \\
\text { dorsal flexion } \\
\text { Mean value of the five } \\
\text { consecutive trials }\end{array}$ & $\begin{array}{l}\text { Kin-Com }{ }^{\circledR} \text { : } \\
\text { ICC } 0.83 \text { at } \mathrm{LV} \\
\text { ICC } 0.75 \text { at } \mathrm{HV} \\
\text { (Means of } 4 \text { trials: } \\
\text { ICC } 0.99 \text { at } \mathrm{LV} \text {; ICC } 0.93 \text { at } \\
\mathrm{HV} \text { ) } \\
\text { Hand-held: } \\
\text { ICC } 0.93 \text { at } \mathrm{LV} \\
\text { ICC } 0.84 \text { at } \mathrm{HV}\end{array}$ & $\begin{array}{l}\text { Kin-Com }{ }^{\circledR}: \\
\text { Resistance } \\
3.14-6.43 \% \\
\text { Velocity } 0.47-7.84 \% \\
\text { Hand-held: } \\
\text { Resistance } \\
7.98-16.11 \% \\
\text { Velocity } \\
12.74-40.43 \%\end{array}$ \\
\hline $\begin{array}{l}\text { Kakebeeke } \\
\text { et } a l^{42}\end{array}$ & $\begin{array}{l}\text { Twenty SCL (C5-T6) } \\
\text { (ASIA A/B) } \\
\text { Minimum } 4 \\
\text { months post injury }\end{array}$ & $\begin{array}{l}\text { Knee flexion and } \\
\text { extension }\end{array}$ & $\begin{array}{l}\text { Cybex Norm II } \\
10^{\circ} / \mathrm{s} \\
120^{\circ} / \mathrm{s}\end{array}$ & $\begin{array}{l}\text { Resistance at two flexion/ } \\
\text { extension movements at } \\
10^{\circ} / \mathrm{s} \text { and } 15 \mathrm{~s} \text { later further } \\
\text { four flexion/extension } \\
\text { movements at } 120^{\circ} / \mathrm{s} \\
\text { Peak torque of the two slow } \\
\text { and the four quick } \\
\text { repetitions }\end{array}$ & $\begin{array}{l}\text { Spearman correlation } \\
\text { coefficient (CC) between the } \\
\text { first and second protocol at } \\
10^{\circ} / \mathrm{s} \text { were moderate and } \\
\text { not always significant. } \\
\text { Extensors: Peak/sum } \\
0.72-0.84 \\
\text { Flexors: Peak/sum } \\
0.22-0.89 \\
\text { CC at } 120^{\circ} / \mathrm{s} \text { were more } \\
\text { stable and high } \\
\text { Extensors: Peak/sum } \\
0.55-0.89 \\
\text { Flexors: Peak/sum } \\
0.64-0.87\end{array}$ & \\
\hline
\end{tabular}

CP, cerebral palsy; SCL, spinal cord lesion; ASIA, American Spinal Injury Association International Standards for Neurological classification (2002; Marino et al 2003); LV, low velocity; HV, high velocity; ICC, Interclass Correlation Coefficient 
Table 5 Publications on muscle resistance to passive mechanical stretch in individuals with upper motoneuron lesion and spasticity graded by Ashworth scale or modified Asworth scale

\begin{tabular}{|c|c|c|c|c|c|c|c|}
\hline Author (s) & Participants & Grading of spasticity & Muscles stretched & Device and velocities & $\begin{array}{l}\text { Determination of } \\
\text { resistance }\end{array}$ & Parameters & Results \\
\hline $\begin{array}{l}\text { Firoozbakhsh } \\
\text { et } a^{l^{44}}\end{array}$ & $\begin{array}{l}\text { Six SCL } \\
\text { One Anterior horn cell } \\
\text { disease } \\
\text { One cerebral vascular } \\
\text { accident } \\
\text { Six C }\end{array}$ & $\begin{array}{l}1-3 \text { on a scale from } 0 \\
\text { (flaccid) to } 3 \text { (most } \\
\text { severe) }\end{array}$ & $\begin{array}{l}\text { Knee extensors and } \\
\text { flexors }\end{array}$ & $\begin{array}{l}\text { Kin-Com }{ }^{\circledR} \\
30^{\circ} \% \mathrm{~s} \\
60^{\circ} \% \mathrm{~s} \\
120^{\circ} / \mathrm{s}\end{array}$ & $\begin{array}{l}\text { Torque at preset } \\
\text { velocities }\end{array}$ & $\begin{array}{l}T_{\max } \text { during flexion and } \\
\text { extension } \\
\text { Sum torque }\left(\sum T\right) \text { of } \\
\text { four consecutive torque } \\
\text { amplitudes } \\
\text { Slope of the linear } \\
\text { regression curves of } \\
\text { torque-velocity data }\end{array}$ & $\begin{array}{l}\text { SCL had larger } \sum T \text { compared to } \mathrm{C} \\
(P<0.0028) \\
\text { SCL had greater sensitivity to the rate } \\
\text { of stretch (Slope of the linear regression } \\
\text { curves of torque-velocity data) for } \sum T \\
\text { compared to } C(P<0.0004)\end{array}$ \\
\hline Perell et $a l^{45}$ & $\begin{array}{l}11 \text { SCL 'Spastic' group } \\
\text { (C5-L1) } \\
\text { Six SCL } \\
\text { 'Flaccid' group } \\
\text { (T11-L1) } \\
10 \text { C }\end{array}$ & $\begin{array}{l}\text { AS } \\
2-4 \\
\text { AS } 0\end{array}$ & $\begin{array}{l}\text { Knee extensors and } \\
\text { flexors }\end{array}$ & $\begin{array}{l}\text { Kin-Com }{ }^{\circledR} \\
30^{\circ} \% \mathrm{~s} \\
60^{\circ} \% \mathrm{~s} \\
120^{\circ} / \mathrm{s}\end{array}$ & $\begin{array}{l}\text { Torque at preset } \\
\text { velocities } \\
\text { Range of motion } \\
25^{\circ}-75^{\circ} \text { of flexion } \\
\text { Using five middle } \\
\text { repetitions of } 10-12 \\
\text { at each speed }\end{array}$ & $\begin{array}{l}\text { Torque of the five } \\
\text { middle repetitions } \\
T_{\max } \text { calculated during } \\
\text { flexion and extension } \\
\text { Sum of four consecutive } \\
\text { absolute 'peak' torques } \\
\left(T_{\text {sum }}\right) \\
\text { Slope of the linear } \\
\text { regression curves of } \\
\text { torque-velocity data }\end{array}$ & $\begin{array}{l}\text { 'Spastic'-group } T_{\max } \text { for extensors at } 60 \\
\text { and } 120^{\circ} / \mathrm{s} \text { was lower }(P=0.0009 \text { and } \\
P=0.0017 \text {, respectively) compared to } \\
\text { 'flaccid' and C. No significant difference } \\
\text { between 'flaccid' and C. } \\
T_{\max } \text { and } T_{\text {sum }} \text { increased linearly with } \\
\text { velocity of knee motion for all groups } \\
(P<0.05) \text {. } \\
\text { Sensitivity to the rate of stretch from the } \\
\text { slope of the regression curve (torque- } \\
\text { velocity data): } \\
\text { - 'Spastic' group had a lower } T_{\text {sum-slope }} \\
\text { compared to 'flaccid' (significant) } \\
\text {-'Spastic' group had a lower } T_{\text {max }} \text {-slope } \\
\text { compared to C (significant) } \\
\text { - 'Spastic' group had a lower } T_{\text {max- }} \\
\text { flexion compared to 'flaccid' and C } \\
\text { (significant) } \\
100 \% \text { of 'spastic', } 90 \% \text { of C and } 67 \% \text { of } \\
\text { 'flaccid' were correctly classified by } \\
\text { classification matrix }\end{array}$ \\
\hline Franzoi et $a l^{46}$ & $\begin{array}{l}\text { Complete thoracic SCL } \\
\text { SCL } 1(n=6) \\
\text { SCL } 2(n=6) \\
\text { 12 C }\end{array}$ & $\begin{array}{l}\text { AS 1-2 } \\
\text { AS } 3\end{array}$ & $\begin{array}{l}\text { Knee extensors and } \\
\text { flexors } \\
\text { Right and left leg tested }\end{array}$ & $\begin{array}{l}\text { Cybex } 6000 \\
30^{\circ} / \mathrm{s} \\
60^{\circ} \% \mathrm{~s} \\
120^{\circ} \% \mathrm{~s}\end{array}$ & $\begin{array}{l}\text { Five flexions and } \\
\text { extensions. } \\
\text { Resting period } 10 \mathrm{~s} \\
\text { Range of motion } \\
25^{\circ}-85^{\circ} \text { flexion }\end{array}$ & $\begin{array}{l}\text { Average of PT during } \\
\text { each of five consecutive } \\
\text { passive joint motions at } \\
\text { each preset velocity }\end{array}$ & $\begin{array}{l}\text { Average PT: } \\
\text { SCL }>\text { C in extensors at } 120^{\circ} / \mathrm{s} \\
(P<0.001) \\
\text { SCL } 1<\mathrm{C}<\mathrm{SCL} 2 \text { in flexors at } 60 \text { and } \\
120^{\circ} / \mathrm{s}(P<0.05) \\
\text { SCL } 1=\mathrm{C}<\mathrm{SCL} 2 \text { in extensors at } 60 \\
\text { and } 120^{\circ} / \mathrm{s}(P<0.005) \\
\text { Between muscle-groups } \\
\text { flexors }>\text { extensors in } \mathrm{C} \\
\text { (extension }>\text { flexion }(P<0.006))\end{array}$ \\
\hline Akman $e t a l^{47}$ & $\begin{array}{l}\text { Twenty-eight SCL } \\
\text { paraplegia } \\
\text { Five SCL tetraplegia } \\
14 \mathrm{C}\end{array}$ & $1-4$ on AS & $\begin{array}{l}\text { Hip adductors, } \\
\text { abductors } \\
\text { Knee extensors, flexors } \\
\text { Ankle dorsal and } \\
\text { plantar flexors }\end{array}$ & $\begin{array}{l}\text { Cybex } \\
15^{\circ} / \mathrm{s} \\
30^{\circ} \% \mathrm{~s} \\
60^{\circ} \% \mathrm{~s} \\
90^{\circ} / \mathrm{s} \\
120 / \mathrm{s}\end{array}$ & $\begin{array}{l}\text { PT during each of five } \\
\text { consecutive joint } \\
\text { motions at each velocity }\end{array}$ & $\begin{array}{l}\mathrm{mT} \text { of five repetitions at } \\
\text { each velocity } \\
\text { Average } \mathrm{mT}(\mathrm{AmT}) \text { for } \\
\text { each motion } \\
\text { Sum of five } \mathrm{PT}\left(\sum T\right) \\
\text { for each joint motion at } \\
\text { each velocity } \\
\text { Average } \sum T\left(\mathrm{~A} \sum T\right) \\
\text { for each joint motion } \\
\text { for the five } \sum T \text { at five } \\
\text { velocities }\end{array}$ & $\begin{array}{l}\text { Sign. difference }(P<0.01) \text { in SCL group } \\
\text { between resistive torque for hip } \\
\text { abduction compared to adduction, } \\
\text { ankle dorsal flexion compared to ankle } \\
\text { plantar flexion. } \\
\text { Spasticity most pronounced in ankle } \\
\text { plantar flexors and hip adductors as } \\
\text { graded from AS. } \\
\mathrm{mT} \text { and } \sum T \text { values in the SCL group } \\
\text { was higher compared to } \mathrm{C}(P<0.01) \text { for } \\
\text { each of above-mentioned joint motions } \\
\text { and at all velocities. }\end{array}$ \\
\hline
\end{tabular}


Table 5 Continued

\begin{tabular}{|c|c|c|c|c|c|c|c|}
\hline Author (s) & Participants & Grading of spasticity & Muscles stretched & Device and velocities & $\begin{array}{l}\text { Determination of } \\
\text { resistance }\end{array}$ & Parameters & Results \\
\hline & & & & & & & $\begin{array}{l}\text { AmT and A } \sum T \text { is positively correlated } \\
\text { to Ashworth grades }(r=0.39-0.76) \\
\text { No linear correlation between torque } \\
\text { values and velocity of joint motion in } \\
\text { SCL or C }\end{array}$ \\
\hline Pisano et $a t^{43}$ & Fifty-three stroke & $\begin{array}{l}\text { MAS } \\
2.4 \pm 1.2 \\
\text { (range } 0-5 \text { ) }\end{array}$ & $\begin{array}{l}\text { Wrist flexors } \\
\text { (flexor carpi radialis } \\
\text { muscle) }\end{array}$ & $\begin{array}{l}\text { Servo-controlled DC } \\
\text { torque motor } \\
10^{\circ} / \mathrm{s} \text { with increments of } \\
10^{\circ} / \mathrm{s} \text { until SRTS was } \\
\text { reached }\end{array}$ & $\begin{array}{l}\text { PT during wrist } \\
\text { extension. } \\
\text { Passive (ISI) and total } \\
\text { (TSI) stiffness indices } \\
\text { given at torque/position } \\
\text { at } 10 \text { and } 200^{\circ} / \mathrm{s}\end{array}$ & $\begin{array}{l}\text { SRTS, the minimum } \\
\text { velocity able to evoke } \\
\text { the stretch reflex in the } \\
\text { wrist flexors, in at least } \\
\text { five of } 10 \text { extensions } \\
\text { Latency (EMG) and } \\
\text { area of the stretch reflex } \\
\text { (EMG), evoked during } \\
\text { a mechanical stretch at } \\
500^{\circ} / \mathrm{s} \\
\mathrm{H}-\mathrm{reflex} \text { latency, } \\
H_{\text {max }} / M_{\text {max ratio }}\end{array}$ & $\begin{array}{l}\text { ISI in patients was higher compared to } \\
\mathrm{C} \text { from previous study }(P=0.0019) \\
\text { TSI in patients was higher compared to } \\
\mathrm{C} \text { from previous study }(P=0.007) \\
\text { SRTS in patients was lower compared } \\
\text { to C from previous study }(P=0.0001) \\
\text { Comparison of the stretch reflex latency } \\
\text { values (EMG) at } 500^{\circ} / \mathrm{s} \text { did not reveal } \\
\text { significant differences between patients } \\
\text { and C from a precious study }(P=0.67) \\
\text { Stretch reflex area (EMG) at } 500^{\circ} / \mathrm{s} \text { in } \\
\text { patients was larger compared to C } \\
(P=0.0001) \\
H_{\text {max }} / M_{\text {max }} \text { ratio in patients was higher } \\
\text { compared to C from a previous study } \\
(P<0.001) \\
\text { TSI, SRTS and SR area were highly } \\
\text { correlated to the Ashworth scores }\end{array}$ \\
\hline Pandyan et $a l^{48}$ & Sixteen stroke & MAS $0,1,1+$ & Elbow flexors & $\begin{array}{l}\text { Portable force } \\
\text { transducer and flexible } \\
\text { electrogoniometer } \\
28-66^{\circ} / \mathrm{s}\end{array}$ & & $\begin{array}{l}\text { Resistance to passive } \\
\text { movement (RTPM) and } \\
\text { Speed }\end{array}$ & $\begin{array}{l}\text { RTPM: } \\
\text { - Impaired arm }>\text { nonimpaired arm } \\
(P<0.01) \\
\text { - MAS } 0 \text { or } 1 \text { in impaired arm }<\text { MAS } \\
1+\text { in impaired arm }(P<0.05) \\
\text { - No significant difference between } \\
\text { MAS } 0 \text { compared to MAS } 1 \text { in impaired } \\
\text { arm } \\
\text { Association between RTPM and MAS } \\
\text { was poor }(\kappa=0.336)\end{array}$ \\
\hline Pandyan et $a t^{49}$ & Sixty-three stroke & MAS 0-3 & Elbow flexors & $\begin{array}{l}\text { Portable force } \\
\text { transducer and flexible } \\
\text { electrogoniometer } \\
86-152^{\circ} / \mathrm{s}\end{array}$ & $\begin{array}{l}100 \text { measurements } \\
\text { taken bilaterally } \\
\text { (nonimpaired and then } \\
\text { impaired arm) }\end{array}$ & $\begin{array}{l}\text { Resistance to passive } \\
\text { movement (RTPM) } \\
\text { Peak instantaneous } \\
\text { angular velocity } \\
\text { calculated from } \\
\text { displacement data using } \\
\text { numerical } \\
\text { differentiation }\end{array}$ & $\begin{array}{l}\text { RTPM: } \\
\text { - Impaired arm }>\text { nonimpaired arm } \\
(P<0.01) \\
\text { - MAS } 0 \text { in impaired arm }<\text { MAS } \neq 0 \\
\text { in impaired arm }(P<0.01) \\
\text { - MAS } 0 \text { in impaired arm }<\text { MAS } 1 \text { and } \\
3 \text { in impaired arm }(P<0.05) \\
\text { - No significant differences between } \\
\text { MAS } 1,1+\text { and } 2 \text { in impaired arm } \\
\text { Correlation between RTPM and MAS } \\
\text { was } 0.511 \text { (Spearmann) }\end{array}$ \\
\hline
\end{tabular}

SCL, spinal cord lesion; C, able-bodied controls; AS, Ashworth scale; MAS, modified Ashworth scale; $T_{\max } / \mathrm{mT}$, maximum peak torque; PT: peak torque; SRTS, stretch reflex threshold speed 
the impaired arm was greater than in the nonimpaired arm. RTPM was greater in those with MAS score $1+$ compared to MAS score 0 or 1 , while speed and PROM was greater for those with MAS score 0 compared to those with MAS score 1 or $1+$ (Table 5).

In a later study, Pandyan et $a l^{49}$ found that RTPM in the impaired arm was greater than in the nonimpaired arm. Likewise, RTPM was greater in those with MAS score higher than 0 compared to those with MAS score 0 . The authors conclude that the MAS did not provide a valid measure of spasticity, but may provide a measure of resistance to passive movement.

In the clinical set up used by Pandyan et al, ${ }^{48,49}$ it is difficult to standardize the stretch velocity, which is an important parameter in comparing resistance to stretch. Further, as they state, the RTPM is measured as force and not as torque, which makes it difficult to compare measurements between and within subjects when the lever arm is not standardized.

\section{Overall evaluation of isokinetic dynamometer measurements}

Isokinetic dynamometers may be of value when an objective and reproducible measure of resistance to passive movement is needed, such as in relation to research projects and drug evaluation. The isokinetic dynamometers permit that the velocity-dependency of the muscle resistance, contributions from intrinsic muscle resistance and stretch-evoked muscle resistance may be determined. ${ }^{46,47,50}$

For the individual resistance and EMG measurement, however, it would be desirable to have a reference measurement for standardization when results from different subjects are being compared. In this way, one could compare measurements of muscle resistance and reflex activity from different muscles with different sizes and morphology. As reference or standardization, we propose to use the torque produced by a maximal peripheral electrical stimulation $\left(M_{\max }\right)$ or the maximal voluntary contraction (MVC). A similar standardization of the accompanying EMG activity from the stretch reflex has already become standard. ${ }^{51,52}$

Future aims may be to develop the methods further and to consider whether it will be feasible to develop new portable or semiportable devices that are easy to use in the clinical setting as described recently by Burridge et $a .^{53}$

\section{Pendulum test}

The pendulum test was introduced by Wartenberg in $1951,{ }^{54}$ and has been evaluated in several subsequent studies. ${ }^{55-59}$ In its most simple form, the patient is seated or lying with the lower leg hanging over the end of a couch. The examiner then extends the leg to the horizontal position, while the patient is told to relax. The leg is then released and allowed to swing freely under the action of gravity. With the use of electrogoniometers, the swing of the leg about the knee joint may be evaluated. In individuals with spasticity, a reduction of the swing is generally found. One way of quantifying this is to calculate the ratio between the initial flexion and the final position of the knee joint measured by goniometers, when the leg has come to a rest. This ratio shows a clear correlation to the severity of spasticity as evaluated by the AS. ${ }^{59}$ The advantage of the pendulum test is its simplicity, and the more refined quantification of the severity of spasticity that is obtained compared to the AS. However, it also has several drawbacks. It depends crucially on how the person is seated and the ability of the person to relax fully. Furthermore, it may only be used to evaluate spasticity in the knee muscles and it seems not to give any useful information in severe spasticity. Finally, it is not possible with the test to dissociate increased resistance in the muscle due to viscoelastic changes from the velocity-dependent resistance due to spasticity. Probably because of these drawbacks, the test has not obtained any wider use.

\section{Electrophysiological methods}

It has been considered in a number of studies whether measurement of the evoked electrical activity from the muscles EMG may be used to evaluate spasticity either alone or in combination with biomechanical measurements. This approach seems logical given that the mechanical response of the muscle to some extent must be proportional to the electrical signal (see however Sinkjaer ${ }^{50}$ ). It should be remembered that measurement of EMG from a relaxed muscle without some kind of manipulation makes no sense, if the aim is to evaluate spasticity. 'Spontaneous' EMG activity is a sign of dystonia or muscle spasms, whereas evaluation of spasticity requires activation of the stretch reflex. Several studies during the past $40-50$ years have consequently used EMG to measure the responses evoked by either stretching of the muscle (stretch reflex), tendon tap (T-reflex) or electrical stimulation of the peripheral nerve supplying the muscle $(\mathrm{H}$-reflex) in order to evaluate whether these responses are exaggerated in spastic individuals and related to the degree of spasticity (Figure 1). Some studies have also measured the EMG response to passive manipulation of the limb by an examiner. ${ }^{60,61}$

There are several problems in such studies. The size of the responses measured in the EMG depends heavily on such factors as the placement of the electrodes, skin resistance, subcutaneous fat, muscle atrophy, etc. It is therefore not possible to compare the absolute amplitude of the responses between or even within subjects from session to session. The responses may, however, be compared from session to session and from subject to subject, if they are expressed relative to the size of the EMG response evoked by a supramaximal stimulation of all motor axons in the nerve supplying the muscle from which the reflex response is measured $\left(M_{\max }\right)$. Unfortunately, this has not been done in several studies and the value of these is therefore limited. 
Table 6 Correlation between electrophysiological findings and clinical spasticity measurements

\begin{tabular}{|c|c|c|}
\hline Author $(s)$ & Participants & Results \\
\hline Shemesh et $a l^{74}$ & Twenty SCL & $\begin{array}{l}H / M \text { ratio increased compared to healthy subjects; } \\
\text { no correlation to clinical spasticity }\end{array}$ \\
\hline Little and Halar ${ }^{73}$ & Six complete SCL & $H / M$ ratio increased in patients compared to healthy subjects \\
\hline Katz et $a l^{80}$ & Ten chronic hemiplegic & $H / M$ ratio not correlated to MAS \\
\hline Harburn et $a l^{75}$ & $\begin{array}{l}\text { Six stroke } \\
\text { Six healthy }\end{array}$ & H-reflex increased in patients \\
\hline Levin and Hui-Chan ${ }^{72}$ & $\begin{array}{l}\text { Ten hemiplegic } \\
\text { Seven healthy }\end{array}$ & $\begin{array}{l}H / M \text { ratio increased in spastic patients, but no clear } \\
\text { correlation with clinical score }\end{array}$ \\
\hline Crone et $a l^{8,81}$ & $\begin{array}{l}\text { Thirty-nine MS } \\
\text { Eleven SCL } \\
\text { Six stroke }\end{array}$ & $\begin{array}{l}\text { Decreased disynaptic reciprocal inhibition in patients; } \\
\text { not correlated to MAS }\end{array}$ \\
\hline Nielsen et $a l^{10}$ & $\begin{array}{l}\text { Twenty-five MS } \\
30 \text { healthy }\end{array}$ & $\begin{array}{l}H_{\text {max }} / M_{\text {max }} \text { higher (nonsignificant) in patients; not correlated } \\
\text { to MAS, but to Achilles reflex exaggeration and clonus }\end{array}$ \\
\hline Milanov $^{70}$ & One hundred and twenty stroke & Moderate correlation $(<0.5)$ of $H_{\max }, T_{\max }$ and MAS \\
\hline Pisano et $a l^{43}$ & Fifty-three stroke & No correlation of $H_{\max } / M_{\max }$ and MAS score \\
\hline Sherwood et $a l^{79}$ & Ninety SCL & Surface EMG-derived scores relate to AS \\
\hline Morita et $a l^{82}$ & $\begin{array}{l}\text { Twenty MS } \\
23 \text { healthy }\end{array}$ & $\begin{array}{l}H_{\text {max }} / M_{\max } \text { higher (non-significant) in patients; not correlated } \\
\text { to MAS }\end{array}$ \\
\hline Bakheit et $a l^{69}$ & $\begin{array}{l}\text { Stroke: } \\
\text { Fourteen with MAS } 1 \\
\text { Ten with MAS } 2\end{array}$ & $\begin{array}{l}H_{\max } / M_{\max } \text { higher in patients than in healthy; nonsignificant } \\
\text { larger size in group with high MAS score }\end{array}$ \\
\hline Schindler-Ivens and Shields ${ }^{77}$ & $\begin{array}{l}\text { Nine chronic complete SCL } \\
\text { Twenty healthy }\end{array}$ & $\begin{array}{l}\text { No change in H-reflex threshold, gain or amplitude as } \\
\text { compared to healthy }\end{array}$ \\
\hline
\end{tabular}

The size of the evoked responses has also been found to depend crucially on the position of the various joints in the examined limb $b^{62,63}$ as well as the position of the head, due to effects from the vestibular system and neck receptors. ${ }^{64,65}$ Ensuring a comparable position of the relevant joints and body segments during all measurements is therefore of importance.

Even in the studies where such control measures have been taken, it has been found that the evoked EMG activity varies significantly within a population of healthy subjects. For instance, the soleus H-reflex varies between 0 and $100 \%$ of the maximal $M$-response. ${ }^{66,67}$ The size of the responses appears to depend on a number of different factors including the level and type of physical activity of the individual, the age of the person and possibly also genetic factors. ${ }^{6,68}$ Despite of this variability, most studies have found that the reflexes, when measured in resting individuals, are larger in a population of spastic individuals as compared to an age-matched population of healthy persons, ${ }^{10,43,69-76}$ see however Schindler-Ivens and Shields. ${ }^{77}$ On the other hand, within the population of spastic individuals, usually no clear correlation is found between the size of the responses and the amount of spasticity as evaluated according to the MAS, ${ }^{10,43,70,72}$ see however Allison and Abraham $^{78}$ and Sherwood et $a l^{79}$ (Table 6). This can be explained either by the described limitations of the AS and the MAS or the large variability of the EMG responses in the population as a whole. It is noteworthy that some healthy persons, without being spastic, have stretch reflexes that are of the same size as in most spastic individuals, and that some spastic individuals have stretch reflexes, which are in the lower part of the normal range (personal observations). This suggests that the clinical diagnosis of spasticity involves more than a simple exaggeration of the phasic EMG responses. Clearly, the mechanical translation of the EMG response and the more tonic part of the evoked stretch reflex activity may play a crucial role also. 
Although electrophysiological measurements on their own thus do not play any significant role in the evaluation of spasticity, there are two areas where they nevertheless have made a significant contribution and may be expected to play an even more significant role in the future. One is that they provide the easiest and most reliable way of determining the stretch reflex threshold and thus may be of value for evaluation of spasticity in combination with biomechanical techniques. ${ }^{31,83,84}$ Based on the studies reviewed in this and the previous section, it would seem reasonable that a 'gold standard' for evaluation of spasticity would involve EMG measurement to determine the stretch reflex threshold and biomechanical techniques to evaluate the relationship between stretch velocity and the evoked stretch reflex-mediated torque generated from the stretched muscles. We believe that further investigation of this combination may prove to be fruitful in the future.

Another area where electrophysiological techniques have already made a significant contribution is in the investigation of the role of altered transmission in spinal neuronal circuitries for the pathophysiology of spasticity. ${ }^{85-89}$ Impaired transmission has been found especially in the inhibitory pathways, which exert presynaptic inhibition of the terminals of stretch reflex afferents and postsynaptic reciprocal Ia inhibition between antagonistic muscles (Figure 2). However, although such studies are of great importance for our understanding of the pathophysiology of spasticity and thus for our future possibilities of refining the diagnosis and treatment of the disorder, it should be pointed out that the techniques used in the studies cannot be used as a way of evaluating the degree of spasticity. Although both presynaptic inhibition and reciprocal Ia inhibition are depressed in a population of spastic individuals as compared to healthy control persons, ${ }^{8-10}$ there is usually no good correlation between the amount of depression and the extent of spasticity within the population of spastic individuals. Noteworthy, there are spastic persons in whom both inhibitory mechanisms appear to function quite well, but who nevertheless are severely spastic - and there are healthy persons, who are naturally not spastic, but in whom the two inhibitory mechanisms cannot be demonstrated. ${ }^{8,81,90}$ This reflects the multifactorial pathophysiology of spasticity and illustrates that measurement of any of these mechanisms is unsuitable as a marker of the extent of spasticity.

\section{Conclusion}

We know that the various tests and measurements assess different aspects of spasticity. To minimize the influence of confounding factors, strict guidelines for the assessment procedures are necessary together with a regular training program for the assessors.

Reliable and reproducible quantitative measures are in particular needed for evaluation of new treatments of spasticity. Further development and standardization of biomechanical techniques may be a possibility for having a valid and reproducible instrument. In addition, a combination of electrophysiological and biomechanical techniques shows some promise for a full characterisation of the spastic syndrome. For the daily clinical routine, simple instruments will be very much appreciated.

\section{References}

1 Kirshblum S. Treatment for spinal cord injury related spasticity. J Spinal Cord Med 1999; 22: 199-217.

2 Maynard FM, Karunas RS, Waring WP. Epidemiology of spasticity following traumatic spinal cord injury. Arch Phys Med Rehabil 1990; 71: 566-569.

3 Young RR. Spasticity: a review. Neurology 1994; 44(Suppl 9): S12-S20.

4 Mayer NH. Clinicophysiologic concepts of spasticity and motor dysfunction in adults with an upper motoneuron lesion. Muscle Nerve 1997; 20(Suppl 6): S1-S13.

5 Sköld C, Levi R, Seiger A. Spasticity after traumatic spinal cord injury: nature, severity, and location. Arch Phys Med Rehab 1999; 80: 1548-1557.

6 Lawrence DG, Kuypers HG. The functional organization of the motor system in the monkey. I. The effects of bilateral pyramidal lesions. Brain 1968a; 91: 1-14.

7 Lawrence DG, Kuypers HG. The functional organization of the motor system in the monkey. II. The effects of lesions of the descending brain-stem pathways. Brain 1968b; 91: 15-36.

8 Crone C, Nielsen J, Petersen N, Ballegaard M, Hultborn H. Disynaptic reciprocal inhibition of ankle extensors in spastic patients. Brain 1994; 117: 1161-1168.

9 Faist M, Mazevet D, Dietz V, Pierrot-Deseilligny E. A quantitative assessment of presynaptic inhibition of Ia afferents in spastics. Differences in hemiplegics and paraplegics. Brain 1994; 117: 1449-1455.

10 Nielsen J, Petersen N, Crone C. Changes in transmission across synapses of peripheral afferents in spastic multiple sclerosis patients. Brain 1995; 118: 995-1004.

11 Crone C, Hultborn H, Kiehn O, Mazieres L, Wigstrom H. Maintained changes in motoneuronal excitability by shortlasting synaptic inputs in the decerebrate cat. $J$ Physiol 1988; 405: 321-343.

$12 \mathrm{Li} \mathrm{Y,} \mathrm{Gorassini} \mathrm{MA,} \mathrm{Bennett} \mathrm{DJ.} \mathrm{Role} \mathrm{of} \mathrm{persistent}$ sodium and calcium currents in motoneuron firing and spasticity in chronic spinal rats. J Neurophysiol 2004; 91: 767-783.

13 Nickolls P, Collins DF, Gorman RB, Burke D, Gandevia SC. Forces consistent with plateau-like behaviour of spinal neurons evoked in patients with spinal cord injuries. Brain 2004; 127: 660-670.

14 Sköld C. Spasticity in spinal cord injury: self- and clinically rated intrinsic fluctuations and intervention-induced changes. Arch Phys Med Rehabil 2000; 81: 144-149.

15 Pierson SH. Outcome patterns of clinical motor dysfunction. Muscle Nerve 1997; 20(Suppl 6): S36-S60.

16 Platz T, Eickhof C, Nuyens G, Vuadens P. Clinical scales for the assessment of spasticity, associated phenomena, and function: a systematic review of the literature. Disabil Rehabil 2005; 27: 7-18.

17 Wood DE et al. Biomechanical approaches applied to the lower and upper limb for the measurement of spasticity: a systematic review of the literature. Disabil Rehabil 2005; 27: 19-32.

18 Voerman GE, Gregorič M, Hermens HJ. Neurophysiological methods for the assessment of spasticity: the 
Hoffmann reflex, the tendon reflex, and the stretch reflex. Disabil Rehabil 2005; 27: 33-68.

19 Ashworth B. Preliminary trial of carisoprodol in multiple sclerosis. Practitioner 1964; 192: 540-542.

20 Bohannon RW, Smith MB. Interrater reliability of a modified Ashworth Scale of muscle spasticity. Phys Ther 1987; 67: 206-207.

21 Sloan RL, Sinclair E, Thompson J, Taylor S, Pentland B. Inter-rater reliability of the modified Ashworth scale for spasticity in hemplegic patients. Int J Rehabil Res 1992; 15: $158-161$.

22 Nuyens G et al. Inter-rater reliability of the Ashworth scale in multiple sclerosis. Clin Rehabil 1994; 8: 286-292.

23 Haas BM, Bergström E, Jamous A, Binnie A. The inter rater reliability of the original and of the modified Ashworth scale for the assessment of spasticity in patients with spinal cord injury. Spinal Cord 1996; 34: 560-564.

24 Allison SC, Abraham LD, Petersen CL. Reliability of the modified Ashworth scale in the assessment of plantarflexor muscle spasticity in patients with traumatic brain injury. Int J Rehabil Res 1996; 19: 67-78.

25 Gregson JM, Leathley M, Moore AP, Sharma AK, Smith TL, Watkins CL. Reliability of the tone assessment scale and the modified Ashworth scale as clinical tools for assessing poststroke spasticity. Arch Phys Med Rehabil 1999; 80: 1013-1016.

26 Gregson JM, Leathley MJ, Moore AP, Smith TL, Sharma AK, Watkins CL. Reliability of measurements of muscle tone and muscle power in stroke patients. Age Ageing 2000; 29: $223-228$.

27 Blackburn M, van Vliet P, Mockett SP. Reliability of measurements obtained with the Modified Ashworth scale in the lower extremities of people with stroke. Phys Ther 2002; 82: $25-34$.

28 Pandyan AD, Johnson GR, Price CIM, Curless RH, Barnes MP, Rodgers H. A review of the properties and limitations of the Ashworth and modified Ashworth scales as measures of spasticity. Clin Rehab 1999; 13: 373-383.

29 Walsh EG, Ashworth B. Scope and limitations of the manual assessment of muscle tone. letter to the editor. Spinal Cord 1997; 35: 64.

30 Thilmann AF, Fellows SJ, Garms E. The mechanism of spastic muscle hypertonus. Variation in reflex gain over the time course of spasticity. Brain 1991; 114(Part 1A): 233-244.

31 van der Salm A, Veltink PH, Hermens HJ, Ijzerman MJ, Nene AV. Development of a new method for objective assessment of spasticity using full range passive movements. Arch Phys Med Rehabil 2005; 86: 1991-1997.

32 Ward AB. Assessment of muscle tone. Editorial. Age Ageing 2000; 29: 385-386.

33 Penn RD et al. Intrathecal baclofen for severe spinal spasticity. $N$ Engl J Med 1989; 320: 1517-1521.

34 Snow BJ, Tsui JKC, Bhatt MH, Varelas M, Hashimoto SA, Calne DB. Treatment of spasticity with botulinum toxin: a double blind study. Ann Neurol 1990; 28: 512-515.

35 Læssøe L, Nielsen J, Biering-Sørensen F, Sønksen J. Antispastic effect of penile vibration in spinal cord lesioned men. Arch Phys Med Rehabil 2004; 85: 919-924.

36 Priebe MM, Sherwood AM, Thornby JI, Kharas NF, Markowski J. Clinical assessment of spasticity in spinal cord injury: a multidimensional problem. Arch Phys Med Rehabil 1996; 77: 713-716.
37 Farrell M, Richards JG. Analysis of the reliability and validity of the kinetic communicator exercise device. Med Sci Sports Exerc 1986; 18: 44-49.

38 Mayhew TP, Rothstein JM, Finucane SDG, Lamb RL. Performance characteristics of the Kin-Com ${ }^{\mathrm{B}}$ dynamometer. Phys Ther 1994; 74: 1047-1054.

39 Snow CJ, Blacklin K. Reliability of knee flexor peak torque measurements from a standardized test protocol on a Kin/Com dynamometer. Arch Phys Med Rehabil 1992; 73: 15-21.

40 Boiteau M, Malouin F, Richards CL. Use of hand-held dynamometer and a Kin-Com dynamometer for evaluating spastic hypertonia in children: a reliability study. Phys Ther 1995; 75: 796-802.

41 Lamontagne A, Malouin F, Richards CL, Dumas F. Evaluation of reflex- and nonreflex-induced muscle resistance to stretch in adults with spinal cord injury using hand-held an isokinetic dynamometer. Phys Ther 1998; 78: 964-975.

42 Kakebeeke $\mathrm{TH}$, Lechner $\mathrm{H}$, Baumberger M, Denoth J, Michel D, Knecht H. The importance of posture on the isokinetic assesment of spasticity. Spinal Cord 2002; 40: 236-243.

43 Pisano F, Miscio G, Conte Cd, Pianca D, Candeloro E, Colombo R. Quantitative measures of spasticity in poststroke patients. Clin Neurophysiol 2000; 111: 1015-1022.

44 Firoozbakhsh KK, Kunkel CF, Scremin AME, Moneim MS. Isokinetic dynamometric technique for spasticity assessment. Am J Phys Med Rehabil 1993; 72: 379-385.

45 Perell K, Scremin A, Scremin O, Kunkel C. Quantifying muscle tone in spinal cord injury patients using isokinetic dynamometric techniques. Paraplegia 1996; 34: 46-53.

46 Franzoi AC, Castro C, Cardone C. Isokinetic assessment of spasticity in subjects with traumatic spinal cord injury (ASIA A). Spinal Cord 1999; 37: 416-420.

47 Akman MN, Bengi R, Karatas M, Kilinc S, Sozay S, Ozker R. Assessment of spasticity using isokinetic dynamometry in patients with spinal cord injury. Spinal Cord 1999; 37: 638-643.

48 Pandyan AD, Price CIM, Rodgers H, Barnes MP, Johnson GR. Biomechanical examination of a commonly used measure of spasticity. Clin Biomech 2001; 16: 859-865.

49 Pandyan AD, Price CI, Barnes MP, Johnson GR. A biomechanical investigation into the validity of the modified Ashworth Scale as a measure of elbow spasticity. Clin Rehabil 2003; 17: 290-294.

50 Sinkjaer T. Muscle, reflex and central components in the control of the ankle joint in healthy and spastic man. Acta Neurol Scand Suppl 1997; 170: 1-28.

51 Crone C, Hultborn H, Mazieres L, Morin C, Nielsen J, Pierrot-Deseilligny E. Sensitivity of monosynaptic test reflexes to facilitation and inhibition as a function of the test reflex size: a study in man and the cat. Exp Brain Res 1990; 81: 35-45.

52 Nakazawa K, Kawashima N, Akai M. Enhanced stretch reflex excitability of the soleus muscle in persons with incomplete rather than complete chronic spinal cord injury. Arch Phys Med Rehabil 2006; 87: 71-75.

53 Burridge $\mathrm{JH}$ et al. Theoretical and methodological considerations in the measurement of spasticity. Disabil Rehabil 2005; 27: 69-80.

54 Wartenberg R. Pendulousness of the legs as a diagnostic test. Neurology 1951; 1: 18-24.

55 Bajd T, Vodovnik L. Pendulum testing of spasticity. J Biomed Eng 1984; 6: 9-16. 
56 Bohannon RW. Variability and reliability of the pendulum test for spasticity using a Cybex II isokinetic dynamometer. Phys Ther 1987; 67: 659-661.

57 Brown RA et al. Does the Wartenberg pendulum test differentiate quantitatively between spasticity and rigidity? A study in elderly stroke and Parkinsonian patients. J Neurol Neurosurg Psychiatry 1988; 51: 1178-1186.

58 Lin DC, Rymer WZ. A quantitative analysis of pendular motion of the lower leg in spastic human subjects. IEEE Trans Biomed Eng 1991; 38: 906-918.

59 Leslie GC, Muir C, Part NJ, Roberts RC. A comparison of the assessment of spasticity by the Wartenberg pendulum test and the Ashworth grading scale in patients with mulsple sclerosis. Clin Rehabil 1992; 6: 41-48.

60 Sköld C, Harms-Ringdahl K, Hultling C, Levi R, Seiger A. Simultaneous Ashworth measurements and electromyographic recordings in tetraplegic patients. Arch Phys Med Rehabil 1998; 79: 959-965.

61 Zupan B, Stokic DS, Bohanec M, Priebe MM, Sherwood AM. Relating clinical and neurophysiological assessment of spasticity by machine learning. Int J Med Inform 1998; 49: 243-251.

62 Cheng J, Brooke JD, Misiaszek JE, Staines WR. The relationship between the kinematics of passive movement, the stretch of extensor muscles of the leg and the change induced in the gain of the soleus $\mathrm{H}$ reflex in humans. Brain Res 1995; 672: 89-96.

63 Gerilovsky L, Tsvetinov P, Trenkova G. H-reflex potentials shape and amplitude changes at different length of relaxed soleus muscle. Electromyogr Clin Neurophysiol 1986; 26: 641-653.

64 Delwaide PJ, Juprelle M. The effects of caloric stimulation of the labyrinth on the soleus motor pool in man. Acta Neurol Scand 1977; 55: 310-322.

65 Traccis S, Rosati G, Patraskakis S, Bissakou M, Sau GF, Aiello I. Influences of neck receptors on soleus motoneuron excitability in man. Exp Neurol 1987; 95: 76-84.

66 Nielsen J, Crone C, Hultborn H. H-reflexes are smaller in dancers from the Royal Danish Ballet than in well-trained athletes. Eur J Appl Physiol 1993; 66: 116-121.

67 Crayton JW, King S. Inter-individual variability of the $\mathrm{H}$ reflex in normal subjects. Electromyogr Clin Neurophysiol 1981; 21: 183-200.

68 Kido A, Tanaka N, Stein RB. Spinal excitation and inhibition decrease as humans age. Can J Physiol Pharmacol 2004; 82: 238-248.

69 Bakheit AM, Maynard VA, Curnow J, Hudson N, Kodapala S. The relation between Ashworth scale scores and the excitability of the alpha motor neurones in patients with post-stroke muscle spasticity. J Neurol Neurosurg Psychiatry 2003; 74: 646-648.

70 Milanov I. Clinical and neurophysiological correlations of spasticity. Funct Neurol 1999; 14: 193-201.

71 Matthews WB. Ratio of maximum $\mathrm{H}$ reflex to maximum $\mathrm{M}$ response as a measure of spasticity. J Neurol Neurosurg Psychiatry 1966; 29: 201-204.

72 Levin MF, Hui-Chan C. Are $\mathrm{H}$ and stretch reflexes in hemiparesis reproducible and correlated with spasticity? J Neurol 1993; 240: 63-71.
73 Little JW, Halar EM. H-reflex changes following spinal cord injury. Arch Phys Med Rehabil 1985; 66: 19-22.

74 Shemesh Y, Rozin R, Ohry A. Electrodiagnostic investigation of motor neuron and spinal reflex arch (H-reflex) in spinal cord injury. Paraplegia 1977; 15: 238-244.

75 Harburn KL et al. Spasticity measurement in stroke: a pilot study. Can J Public Health 1992; 83: S41-S45.

76 Toft E. Mechanical and electromyographic stretch responses in spastic and healthy subjects. Acta Neurol Scand Suppl 1995; 163: 1-24.

77 Schindler-Ivens SM, Shields RK. Soleus H-reflex recruitment is not altered in persons with chronic spinal cord injury. Arch Phys Med Rehabil 2004; 85: 840-847.

78 Allison SC, Abraham LD. Correlation of quantitative measures with the modified Ashworth scale in the assessment of plantar flexor spasticity in patients with traumatic brain injury. J Neurol 1995; 242: 699-706.

79 Sherwood AM, Graves DE, Priebe MM. Altered motor control and spasticity after spinal cord injury: subjective and objective assessment. J Rehabil Res Dev 2000; 37: 41-52.

80 Katz RT, Rovai CP, Brait C, Rymer WZ. Objective quantification of spastic hypertonia: correlation with clinical findings. Arch Phys Med Rehabil 1992; 73: 339-347.

81 Crone C, Johnsen LL, Biering-Sorensen F, Nielsen JB. Appearance of reciprocal facilitation of ankle extensors from ankle flexors in patients with stroke or spinal cord injury. Brain 2003; 126: 495-507.

82 Morita H, Crone C, Christenhuis D, Petersen NT, Nielsen JB. Modulation of presynaptic inhibition and disynaptic reciprocal Ia inhibition during voluntary movement in spasticity. Brain 2001; 124: 826-837.

83 Chou SW, Abraham LD, Huang IS, Pei YC, Lai CH, Wong AM. Starting position and stretching velocity effects on the reflex threshold angle of stretch reflex in the soleus muscle of normal and spastic subjects. J Formos Med Assoc 2005; 104: 493-501.

84 Kim DY, Park CI, Chon JS, Ohn SH, Park TH, Bang IK. Biomechanical assessment with electromyography of poststroke ankle plantar flexor spasticity. Yonsei Med J 2005; 46: $546-554$.

85 Burke D. Spasticity as an adaptation to pyramidal tract injury. Adv Neurol 1988; 47: 401-423.

86 Pierrot-Desilligny E. Electrophysiological assessment of the spinal mechanisms underlying spasticity. Electroencephalogr Clin Neurophysiol 1990; 41(Suppl): 264-273.

87 Nielsen J, Hultborn H. Regulated properties of Motoneurons and Primary Afferents: New aspects on Possible Spinal Mechanisms underlying Spasticity. In: Thilmann et al. (eds). Springer Verlag: Berlin 1993, pp, 177-191.

88 Katz R. Presynaptic inhibition in humans: a comparison between normal and spastic patients. J Physiol Paris 1999; 93: $379-385$

89 Hultborn H. Changes in neuronal properties and spinal reflexes during development of spasticity following spinal cord lesions and stroke: studies in animal models and patients. J Rehabil Med 2003; 41(Suppl): 46-55.

90 Crone C, Hultborn H, Jespersen B, Nielsen J. Reciprocal Ia inhibition between ankle flexors and extensors in man. J Physiol 1987; 389: 163-185. 